\title{
The Poetics and Politics of Affect and Access in Selected Poetry by Julia Alvarez
}

\section{Naglaa Saad Mohamed Hassan*}

Nsm01@fayoum.edu.eg

\section{Abstract}

Taking threads of affect theory as a speculative backdrop, this study is to demonstrate how Julia Alvarez's poems reflect the politics of affect and access in Latino-American context. Hinging on Baruch Spinoza's view that melancholy and happiness are the two major affects out of which other positive and negative ones, including fear, pain, shame and pride, spring out, and advocating the view of the Australian British thinker, Sara Ahmed on the politics of affects in general and happiness in particular, the study is to show how Alvarez's poetry conveys the wavering affects the Dominican American migrant experiences in the attempt to gain social, linguistic, professional and literary access to the mainstream white community. To achieve its objectives, the study is to be divided into two parts: the first part is to present an overview of the lexicographic, epistemic rooting of the concept of "affect" and introduce the reader to Spinoza and Ahmed's views on positive and negative affects with particular focus on happiness and melancholy, and the second part is to read selected poems by Alvarez in light of the speculative background illustrated . In addition to enriching the increasingly growing affect theory scholarship, the importance of the study lies in foregrounding the virtuosity of Alvarez' poetic vision, which, in contrast to her prose, has not received its due critical attention.

Key words :Affect theory, Julia Alvarez, Spinoza, happiness, melancholy, Sara Ahmed, happiness objects.

\footnotetext{
*Associate Professor- English Department -Fayoum University
} 


\section{Theoretical Background}

To read a literary text using affect theory as a methodological approach, it is necessary to clarify the lexicographic and epistemic rooting of the term "affect." Lexicographically, "affect", which is borrowed from the Latin "affectus", refers to "a set of observable manifestations of a subjectively experienced emotion" (Merriam Webster; emphasis added). In psychological dictionaries, affect is "any experience of feeling or emotion, ranging from suffering to elation, from the simplest to the most complex sensations of feeling, and from the most normal to the most pathological emotional reaction" (APA Dictionary; emphasis added) Plainly, therefore, the idea of "experience," "reaction" and "manifestation" is what differentiates affect from emotion given that the former is oft tied with some physical re-actions.

Epistemologically", the term "affect" stretches back to the classical era. In the introduction to the edited book Passions and Moral Progress, John Fitzgerald shows how the word "affectus" or "adfectus" was used by "most post-Ciceronian authors", who perceived "it as a negative type of emotions" (4). Citing the

${ }^{1}$ For the purpose of its argument, the paper at hand focuses on limited views on affect. For a broader guide to the history of philosophies of affect, see John Brenkman's Mood and Trope The Rhetoric and Poetics of Affect . 
Roman rhetorician Marcus Fabius Quintilianus and the Roman philosopher Lucius Annaeus Seneca, Fitzgerald indicates how adfectus was used interchangeably with "pathos" to refer to "irrational" and "violent emotions" including anger, hatred, fear, envy and pity (4).

Such limitational view of affect was refuted by the sixteenth century philosopher Baruch Spinoza whose postulations, adopted and re-envisioned by the French philosopher Gilles Deleuze, arguably form the basis of contemporary affect theory. In his book Ethics, Spinoza refers to affects as "states of mind and body". Affects, he writes, are "affections of the body by which the body's power of acting is increased or diminished, aided or restrained, and at the same time, the ideas of these affections" (154). From a Spinozian angle, therefore, affect ties the mind with the body on the one hand, and the intensities of feelings with the power of acting and re-acting, and hence to striving and self-preservation on the other. In his revision of Spinoza, French philosopher Gilles Deleuze illustrates that what distinguishes Spinozian affect is the transformation it brings about:"affectus is thus the continuous variation of someone's force of existing, insofar as this variation is determined by the ideas that $\mathrm{s}$ /he has...[it] is the continuous variation or passage from one degree of reality to another or from one degree of perfection to another" (On Spinoza's Affect). For Spinoza, "all affects proper derive from what is essential to the mind" and 
hence, there are two primary affects: joy [Laetitia] and sadness [tristitia], which both "are species of desire ... aided by external causes" (57) . Continuing his review of Spinoza's thought, Deleuze illustrates how, as an affect, joy demonstrates "an increase in the power of acting", whereas "sadness ...(is) a diminution or destruction of the power of acting" (On Spinoza's Affect). In his book A Thousand Plateaus, co-authored with Felix Guattari, Deleuze, further enhancing the Spinozian stance, associates affect not merely with the power to act and be acted upon but with power per se. Affect, they maintain, is neither a characteristic nor a personal feeling, it is what distinguishes one human being from another:

We know nothing about a body until we know what it can do... what its affects are, how they can or cannot enter into composition with ...the affects of another body, either to destroy that body or to be destroyed by it, either to exchange actions and passions with it or to join with it in composing a more powerful body (257).

If affect is what distinguishes one human being from another, it follows that it is closely entangled with identity construction.

Building on Spinozian Deleuze-reviewed theory, there emerged a considerable number of affect definitions ${ }^{2}$ which

\footnotetext{
${ }^{2}$ It is w orth noting, that Spinozian Deleuzian notion of affect forms one aspect of the multifaceted orientations of affect in affect theory studies. In his book, Non
}

(The Poetics and Politics of Affect and Access...)Dr. Nagla Saad M. Hassan 
enhance the wedding of the physical with the non-physical and foreground the power of acting. In the much-consulted book Affect Theory Reader, Gregory f. Seigworth \& Melissa Gregg maintain that "affect arises in the midst of inbetweenness: in the capacities to act and be acted upon" (2). The idea of inbetweeness, of relationality, of the power to act and be acted upon brought affect to the realm of ethnic studies and tied it with the seminal concept of "access". Ulla Berg writes that an "analytical focus on affect gives us a vocabulary to talk about intersubjectivity in a way that does not negate, but in fact necessarily evokes, a series of broader material conditions and historical trajectories of which populations of color are highly conscious" (654 ). To the same effect, Jessie Forsyth et al add "affects and access ... relate to distance and proximity, collaborative possibility and denial, identity construction and identity disruption" (108).

A very important affect theoretician who wrote extensively on the politics of affect in ethnic and feminist context

Representational Theory : Space Politics Affect, Nigel Thrift provides a significant three-fold classification of affect definition in affect studies. The first is related to social interactionalism relating emotion to every day behavior and is hence sociological, phenomenological in nature. The second perceives of emotions as "manifestations of the underlying libidinal drive"( 61 ) and has, therefore, Freudian psychological dimension. The third is based on SpinozianDeleuzian perspective which ties affects to "action and encounters as the affections of substance or of its attributes and as greater or lesser forces of existing" (62) and is therefore, naturalistic in essence. 
is Sara Ahmed. Although Ahmed has tackled different affects particularly in her book the Cultural Politics of Emotion, she has given happiness and melancholy a greater interest. In her essay "Happy Objects", Ahmed ties happiness to objects showing how "groups cohere around a shared orientation toward some things as being good, treating some things and not others as the cause of delight" (Affect Reader 35). She illustrates that people do not have the same orientation towards the same objects; things that make us happy do not necessarily bring forth happiness in others. For Ahmed, " the promise of happiness is what sends happiness forth; it is what allows happiness to be out and about" (35). Ahmed uses the terms "happy objects", " happy "pointers" and "happiness means" to refer to different objects, including "social goods" which bring forth happiness. Concentrating on the migrant context, Ahmed shows how most of the families are in continuous quest for the "qualities or attributes that would make for a good or happy life" (Promise 80). For her, happiness involves "a technology of cultivation", of "cultivating subjects "in the right way" so they will flourish". She adds that "the failure to flourish is not the failure of care or orientation but the failure of the earth to yield. For some, the earth is unyielding, unable to provide the soil in which life can flourish"(80). The idea of cultivation, of the yielding earth - which can metaphorically stand for motherland and adopted new land-, one can argue, further entwine happiness with access. Tying happiness with access, she 
shows how in the migrant context, "the unyielding earth provides the grounds of whiteness, as the restriction of life possibility, as giving life to some and not others" ( Promise 81).

In the succeeding part, therefore, the paper is to trace the feasibility of such theoretical threads when used in the reading the poetry of Dominican American poetry, Julia Alvarez. Hinging on the view that "migration ...[is] a key social process and a site for the production of racial affect" (Berg 655) and that the discourse of affect, which is "vital set of dynamic registers of everyday life practices " (655), is closely related to the politics of race, the paper is to show how Alvarez's verses poetically reflect the nuances of Spinozian affective experience and Ahmed's politics of happiness and unhappiness in the Dominican American migrant context.

\section{Affect and Access in Julia Alvarez's poetry}

Informed by her biographical background, Alvarez's poetry displays the conflictual affects experienced by a Dominican migrant family in the USA, the promised land of " magic". The daughter of a Dominican political activist, Alvarez and her family had to flee the island and to live in an opted exile in the USA to escape the state-imposed clampdown on the father. As we read through her oeuvre, we witness the nuances of such affective experience, the interlocking of shame, fear and melancholy entangled with the attempts for social, linguistic and access and its associative Spinozian happiness. In fact, using 
intensive well-crafted imagery, the poet brings the reader right into the affective experience of the Dominican American migrant with the wavering acting and non-acting, happiness and unhappiness entangled with everyday particularities in the adopted homeland. In the succeeding three subsections, therefore, the study is to trace such affective experience right from its very start.

\subsection{Moving In, Shrinking Away:}

\section{Conflictual Affects in the Early Days of Migration}

The six of us marching abreast, arms hooked into each other's , Singing the USA anthem to the tune of a good q1xmerengue.

But as the plane lifted off from our motherland island,

The ground of familia gave, and the craziness started (The Other Side 116 ).

As clear in the above stanza, Alvarez brings the reader into the affective experience right from its very outset. The "craziness" summing up the negative affects created in the migrant's mind and body upon his arrival in the new continent is unleashed in meticulous details in various poems across her oeuvre particularly in her two collections, the Other Side (1995) and the Woman I Kept to Myself (2011). In her poem "Exile", we embark on the journey with the Dominican family as they were "fleeing the country." Playing on the image of swimming with its intense symbolism of potential happiness and fear, the poet persona, then a ten- year old girl, recounts how she and her three sisters, were deceived into believing that they "were going to the beach", how the mother further cultivated the seeds of potential happiness inside them when she "dressed" them in their "best 
dresses" promising to relish an exquisite holiday in the land of "magic." Despite such fake ceremonies, the father figure is caught wrapped in his melancholy. Hence, while driving "past the gates/ in the black Ford", he is seen" grim at the wheel"; before they "stepped inside the [plane]cabin", his eyes "scanned the horizon", knowing " that a part of ...[them] had been set adrift". Further, "weeks later", while the family is "wandering .. [their] new city", the father, still apathetic and unenthusiastic, deflates the exaggerated wonders of the newly adopted homeland through an objective scientific analysis:

you tried to explain the wonders : escalators As moving belts; elevators: pulleys and ropes; Blond hair and blue eyes: a genetic code (The Other Side 27).

Notably, the family's first confrontation with their exilic and othered reality is depicted by picking up the beach image earlier established at the head of the poem:

We stopped before a summery display window At Macy's, The World's Largest Department store, To admire a family outfitted for the beach:

The handsome father, slim and sure of himself

So unlike you, Papi, with your thick mustache, Your three- piece suit, your fedora hat, your accent. And by his side a girl who looked like Heidi In my storybook waded in colored plastic.

We stood awhile, marveling at America Both of us trying hard to feel luckier Than we felt, both of us pointing out The beach pails, the shovels, the sandcastles, 
No wave would ever topple, the red and blue boats (The Other Side 27-28).

The father stands out as inferior, different, and othered. Although he is flesh and blood, he shrinks in comparison with the white lifeless plastic mannequin which, "so unlike" him, is "sure of himself" . The lively expectations-full daughters fail to "feel luckier/than ... they felt". Ironically, the beach trip promised before travel metamorphoses into the scene in the consumerist window display through which the family gets insinuation at what they are up to. Happiness is granted to those who are white, those who are not threatened by any "wave that would ever topple" their dazzling "red and blue boat" whose colours bring to mind the American flag. In contrast, the migrant family is as insignificant and vulnerable as are their "reflections" which are "superimposed" on the mainstream community. Overwhelmed by their own difference and otherness, the family shrinks away from the display window:

And when we backed away, we saw our reflections Superimposed, big-eyes, dressed too formally

With all due respect as visitors to this country.

Or like, Papi, two swimmers looking down At the quiet surface of our island waters, Seeing their faces right before plunging in. Eager, afraid, not yet sure of the outcome (The Other Side 28). 
The image of bodily "backing away" marks the family's realization of their "strangeness"; it is the climax of what Sarah Ahmed calls "strange encounters"- that moment during which the migrant's self-image as a stranger is constituted. For Ahmed, bodies are differentiated into "familiar" (assimilable) and "strange" (unassimilable); the boundary between bodies is created "through the assumption of a bodily image...[which] involves practices and techniques of differentiation...the body becomes imagined through being related to, and separated from, particular bodily others" ( Strange Encounters 44). Notably, the chain of simile vehicles whereby the immigrants' withdrawal is compared ends up with that of swimmers in foreign waters. Like people coming to their Dominican island, the family remain "visitors", at once visible and invisible, inside and outside. Their vulnerable bodies are afflicted with the dense negative affect of fear warring with positive excitement and joy associated with swimming in new waters. It is eagerness mixed with apprehension as to what is to happen thereafter.

Therefore, the family, "newly arrived/ foreign dirt still on ..[their] soles", quickly come to realize that "everyone seemed more American than" them (The Other Side 31). The sense of being uprooted, of not fitting in with its consequent creation of melancholy is picked up in a series of poems. In 'Weeping Willow" included in her volume The Woman I Kept to Myself, Alvarez uses deftly knitted imagery to hammer home the nuances 
of the quest for social access in the white community and the associated afflictions enacted upon their bodies.

The first time I saw my father crying

We were already living in New York

In a dark sublet on a second floor,

From which we could see nothing but concrete-

Some buildings, a cold and marbled sky-

More like the landscape of a prison yard

With pale jailors speaking gibberish

Than the dictatorship we had escaped .

Amid the noise of traffic and English,

It was a silent world - till Papi cried (The Woman 7).

Through the father figure, the poet shows the heavy affective toll acted upon his migrant body. The father's crying is a sign of his consciousness of being a stranger. He has developed what Sara Ahmed refers to as a "consciousness of unhappiness". Notably, Ahmed equates the consciousness of un in "unhappy with "a consciousness of being not. ... of being already estranged from happiness, of lacking the qualities or attributes required for a happy state of existence....Consciousness of being not involves self-consciousness; you recognize yourself as the stranger" (Killing Joy 589). In the migrant context, therefore, unhappiness is attached to exilic white-created estrangement. Note how the poet succeeds in technically enhancing the father's unhappiness and sorrow. The image of crying repeated twice at the beginning and end of the stanza comes in direct opposition to that of silence and darkness (dark sublet, we could see nothing but concrete). 
Nature and culture; space and people unite to intensify the state of melancholy. Hence, the image of the man-made concrete which goes hand in hand with that of the "cold" and "marbled" sky. In Spinozian terms, the father's bodily re-actions further reflect the sense of non-acting negative affect. In addition to crying, he is seen bending and holding his sides:

He bent over his chair, holding his sides, While Mami rushed around, shutting windows, Afraid the Super would warn us again About the level of our noise, the smell Of garlic wafting through our vents (The Woman 7).

With the mind formulating the "confused idea" of inferiority and the threat of blockage from the mainstream community, the father's body tends to shrink and bend while the mother is hurrying to shut the windows. The white master, on the other hand, is imaged as a jailer or the "Super", who, reminiscent of the tyrannical Big Brother of George Orwell's 1984, manifests the state of surveillance, visibility and seclusion imposed on the family. In such alienating space, the Dominican immigrants turn to domestic practices as "objects of happiness". Sara Ahmed maintains that happiness emanates from: "a world of familiar things" (happy objects 32), arguing that such objects are inseparable from identity construction. For her, "objects that give us pleasure take up residence within our bodily horizon. We come to have our likes, which might even establish what we are like. 
The bodily horizon could be re-described as a horizon of likes. To have our likes means certain things are gathered around us" (Happy Objects 32).Ironically, however, in this densely racist surrounding, the migrant family have to avoid the very habits nurturing their exiled souls. Their loud voice and native food aroma - such domestic sociable signs, to which they cling as "happiness means" and which define who they are, further stamp them as marginalized outsiders. With the mother hushing down the crying sound of the father, the inability to act is thoroughly pinned down:

When Mami hushed him, Papi wiped his face, Burying his grief inside his handkerchief (The Woman 7).

As the poem draws to a close, we get to know that the secluded family had to look for another house in which they might enjoy what one might call exilic in-house freedom : "a year later, we rented a small house / with its own yard in which there grew a tree". (The Woman 8) At the end of the poem, the cold sky met earlier turns into a blizzard effacing the features of the newlyrented house:

We watched the backyard slowly fill with snowThe bushes, lawn chairs, swing set, garbage pails, The branches of the willow disappeared, And one by one we all burst into tears (The Woman 8).

Melancholy is contagious. The poem starts with the father crying and ends with the whole family bursting into tears. The image of snow slowly filling the house backyard is symbolic of the 
persistent barriers built up by the white community. The demarcating lines between our place and theirs are further deepened and the difficulty of access still informs the family's life and determining the bodily affective reactions concomitant with such imposed state of seclusion.

In the titular poem, "the Other Side", Alvarez shows how "their" racism, which is "an ideological justification for some of the most cruel and barbaric practices in human history...[providing] a cover up for the brutal exercise of power over the bodies of others" (Joran and Weedon 258) led the parents to a willful seclusion in which they were to enjoy pride in their own peculiar life away from the racial intrusion of the white community,

So many years of hearing, "God back to where you came from!"

Of being out looking in created a certain cynicism-

This was their USA, their Vietnam, their racism, $\cdots$

A pride of separateness led to a habit of seclusion Until even the friendly knock seemed an unwelcome intrusion.

A happy immigrant home might have offset the unwelcome ! (emphasis in original The Other Side 116). The antithetical state of being "in" and "out" creates the seclusive state through which the poet persona forcefully dissociates herself from that world declaring it to be theirs. The pride of separateness shows how the family resorts to their own domestic daily rituals 
as a means of avoiding white-imposed unhappiness. Unable to have access in the wider outside world, the migrant family creates objects of happiness inside their home.

While such willful seclusion works out in the case of parents, it is not feasible with the daughters who are forced to go out of homes into American schools in which they have to face "white girls" and respond to the abusive tunes of "Chiquita Banana". The importance of schooling in minority context is underlined by David Lloyd contends that "for the minority... schooling involves not merely passage from family... to school but also passage from an ethnic group into the dominant culture"( 230 ) adding that this "factor constitutes the contradictory and irrevocable relation of dominant culture to its minorities" (230). Such passage is fraught with intensive affective experiences in which the migrant sometimes has to fight back multi-faceted racial ostracization. In "Spic", Alvarez takes her readers into the white American school of the little migrant girls to further show the link between the intensity of affects and the social and linguistic access. Playing on "spic", an offensive slang word referring to Latin American immigrants living in the USA, the poet displays the affective negative toll exercised on the girls during such passage:

Out in the playground, kids were shouting Spic!

Lifting my sister's skirt, yanking her slip.

Younger, less sexy I was held and stripped

Of coat and bookbag. Homework tumbled out

(The Poetics and Politics of Affect and Access...)Dr. Nagla Saad M. Hassan 
into oncoming traffic in the street irregular verbs crumpled under tires of frantic taxis, blew against the grates of uptown buses we would later take when school let out, trailed by the cries of spic what did they want these American girls? (The Woman 27).

The lines above capture in heart-rending details the process of creating the negative affects of grief, shame and pain which, for Spinoza, all belong to the category of sorrow. They also reflect what Sara Ahmed calls "the physicality of shame- how it works on and through bodies ... [and] involves the de-forming and reforming of bodily and social spaces as bodies turn away from the others who witness the shame" ( Politics 103). Weighed down by the racial secluding shame-producing gaze and the yoke of inaccessibility, the two girls mentally and physically shrink away. They are both inside and outside; included and excluded. The girls' inability to grasp the meaning of the slang word "spic" adds up to their helplessness. With their fragile bodies offended by sexual and physical harassment and their minds crippled by vague untranslatable words, they lose the battle. Their crumbled souls and their defeated bodies are paralleled by the "tumbled homework", the "crumpled irregular verbs", images which exacerbate the blockage of the learning and assimilation process . Notably, Alvarez makes a perfect use of auditory and visual imagery to hammer home the intensity of the situation. The traffic noise with its connotations of city pollution echoes the 
offensive words polluting the girls' ears and psyches to further strengthen the failure of access. The chain of visual images through which Alvarez describes the physical harassment they are subject to are further authenticated by the use of transitivity and passive voice. In contrast to the series of dynamic verbs used in relation to animate (the offenders) and inanimate objects ( the homework, the irregular verbs, , the tires of frantic taxis,), there is scarcity of verbs used with the girls. The passive voice in "I was held and stripped" further supports the powerlessness of the girls torn as they are between external torture and inner subdual due to fear and pain. The images of the personified "homework" and "verbs" hints at the potential role of language in the fight over bodily affects. The white community uses the mechanism of naming to bracket and other the immigrant whose mind, unconsciously grasp that he is to fight back by mastering the language of the citizen/master. In the scene above, both body and language "crumple" under the racial offense.

In the succeeding stanzas, the poet shows how the mother also plays on language to protect her daughters from the negative affective consequences of othering, to guard them against the affect of shame and cultivate its opposite, pride In affect theory, shame and pride are two antithetical self-assessment Spinozian affects that work at the individual and group level. Hence, one can experience shame and pride because of his individual acts but he can also be inflicted by shame because of belonging to a 
certain group; hence the communal shame heaped upon minorities as a result of the Western inscribed white/superiority -nonwhite/inferiority dyad. In her attempt to thwart white-imposed shame and sow the seed of pride in her daughters, the mother purposefully misinterprets the word "spic":

That night when we asked Mami, she explained: our classmates had been asking us to speak, not to be so unfriendly, running off without a word. "This is America! The anthem here invites its citizens to speak up. Oh see, can you say," she sang, proving her point, making us sing along. She winked at Papi, who had not joined in but bowed his head, speaking to God instead "Protect my daughters in America." ( The Woman 27).

Language is again the weapon in such battlefield over affective power and access. She invites her daughters to speak up in order to break the social barriers. The openness, self-confidence and positivity associated with the word "speak" come in sharp contrast to the limitation, shamefulness, and ostracization propelled by the word "spic". Notably, the melancholic father does not join in the mother's tactics. As is the case in the previous poem, his body movements reflect the passivity associated with negative sorrow. Hence, the father; humiliated, "bows his head"; helpless, he "speaks to God". Sticking to the mother's advice, the girl starts to speak up over and again. Yet, ironically, the louder she speaks, the more humiliated, harassed and ostracized she is :

I took her at her word: I raised my hand, 
Speaking up during classes, recess time.

The boys got meaner. Spic ball! They called out,

tossing off my school beanie, playing catch

While I ran boy to boy to get it back.

They sacked my stolen lunch box for their snacks, dumping the foreign things into the garbage bin, Spic trash! But I kept talking, telling them how someday when I'd learn their language well, I'd say what I'd seen in America (The Woman 28).

In terms of Sara Ahmed's theory, unhappiness happen through an event: "An event happens. And it happens again. The violence is directed from the white body to the ...[ non - white] child" (Promise 82). The frequent harassment episodes, enhanced by the use the parallel comparative structure, are meant to cultivate shame and unhappiness in the little girl, who, thanks to the mother's tactical advice, keeps speaking up her confined self. In Spinozian terms, steady talking is a positive affective form of acting through which the girl overcomes the negative sorrowful affects of shame and fear whose seeds were implanted when they set foot in the new continent; the body fights back and unconsciously challenges the White oppressor.

It is notable, however, that although the mother works hard to save her daughters the negative affects of fear and shame, she is unable to rid herself of melancholic worries and fright. Hence, in "Bellevue", the reader beholds a grief-ridden mother who admits that by migrating to the States, she "wanted lives she had raised them not to want". She is loaded with worries about the "so many tempting things in this new world," this world, wherein 
" so many young girls [are] on their own". Sometimes, the mother would leave the house, threatening to go to "Belleveue", her Dominican island "where the world is safe, the grates familiar,/ The howling not unlike her stifled sobs/ as she drove around and around ... [their]block" (The Woman 26). Most often, however, she suppresses her worries resorting to different strategies in this battle over affect and access. It is the mother, who despite choosing to remain in willful seclusion, strives to open up the route for multi-faceted access and equip her daughters with the necessary tools for "the blonde blue-eyed possibilities."

\subsection{The Blonde Blue-Eyed Possibilities:}

\section{Textuality and the Struggle for Affective Power}

I felt a visceral yank at the center of my being,

As if an umbilical cord were being strained to the utmost-

All it needed was the jolt of my pen landing on paper

For the cord to snap off and leave pathetically stranded

On the snowy blank page struggling with a new language (The Other Side 116).

In her book The Willful Subject, Sara Ahmed introduces the term "willful migrant" to refer to the type of subject who uses all tactics to be integrated into the mainstream community. The term is fully applicable on the mother who keeps using all tactics to enable her daughter to gain the affective battle. Hence, realizing the naivety of misinterpreting the swearing words to her gradually growing daughters, the mother decides to confront them with the truth. While in a previous poem, we have caught her 
lying about the meaning of spic, in other poems we witness her employing the strategy of uncompromising self-confrontation:

Keep your voices down, girls

You sound like a hell of a s Hesperus,

Like birds out of hand, like six of one

And six dozen of the others, you sound

Green behind the ears, like a polka

By the fire, you girls are making molehills

By letting sticks and stones hurt you.

They call you spics, what do you care?

It's not in the dictionary, so there.

Speak in your English because

You should do as the Romans do.

Now callense la boca ya acuestense.

I don't want to hear another word.

I don't want to hear another word (The Other Side 41).

The sticks and stones referred to continue the chain of physical abuse heaped on the migrant's vulnerable defenseless body. Although she reveals the true meaning of the swearing words, she is still keen on cultivating pride and happiness in her daughters' soil. Hence, her reference to the Romans and her emphasis on the insignificance of the swearing words based on their exclusion from the dictionary. She is quick to negate the effect of the physical abuse on the mental self-image likely to be promoted in the girls:

Translate yourself, nina,

You won't last long as you are,

Not here in the Estates,

... Translate your café con leche

Into a glass of plain milk

(The Poetics and Politics of Affect and Access...)Dr. Nagla Saad M. Hassan 
Put something else in your mouth

Put English words in your mouth

Give yourself over, girl

To blonde, blue-eyed possibilities

So that even as a brown-haired

Olive-skinned spic chick,

You can click with the gringas

You can jive, you can swing, iepa

Like you are here on a personal invite

From the United Stated of America" (the Other Side 41).

"The blonde blue-eyed possibilities" sums up the minorities' dreams of full access into the white community. The mother's advice to adopt English echoes Fanon who believes that 'the more the black Antillean assimilates the French language, the whiter he gets" (Black 2). Note how the mother refers to "clicking", "jiving" and "swinging", such bodily movements which are symptomatic of joy. In terms of Ahmed's theory, language is the girl's "happiness means", the object whereby the "olive-skinned spic" can move forward from non-acting melancholy to affective happiness. Let us recall how Ahmed affirms that "the promise of happiness ...directs life in some ways rather than others.... The promise of happiness takes this form: if you do this or if you have that, then happiness is what follows" (41). Picking up the mother's advice, the daughter in "All-American Girl" "give" herself away to "blonde possibilities" starting what one can call Americanization rituals with the hope that happiness is to follow.

I wanted stockings, makeup, store-bought clothes;

I wanted to look like an American girl; to speak my English so you couldn't tell

I'd come from somewhere else. I locked myself 
in the bathroom, trying to match my face with words in my new language: grimace, leer, disgust, disdain-feelings I had yet to feel in English. (And would tristeza even feel the same as sadness with its Saxon sound? Would pity look as soulful as piedad? (The Woman 29).

From a semiotic angle, the desired elements of clothes are the signifiers that help the migrant girl be accepted as an American citizen. They are to transform her identity- the signified- from an outsider to a seamless all-American girl. Instead of an invisible excluded other, the girl hopes to be a visible accepted member of the mainstream community. Yet, clothes do not suffice in the process of racial-transformation; language remains a primary tool. Yet, as clear in the above stanza, although the girl tries hard to master the language with its specificities, she is unable to breach the gap between the words and their associative emotive and facial expressions. It is not coincidental, therefore, that all the exemplary words provided by the girl carry negative affective associations: grimace, leer, disgust, disdain. In the succeeding stanzas, she further elaborates on the gap between borrowed language and feelings while, at the same time, shedding light on "striving" to look like an All-American girl:

I didn't know if I could ever show genuine feeling in a borrowed tongue.

If cortesía would be misunderstood as brown-nosing or cries of alegría translate as terror. So, mirror in hand, I practiced foreign faces, Anglo grins, repressing a native Latin fluency for the cooler mask of English ironies. I wanted the world and words to match again as when I had lived solely in Spanish. 
But my face wouldn't obey-like a tide it was pulled back by my lunatic heart to its old habits of showing feelings (The Woman 29-30) .

Alvarez's detailed images on the struggle between words and affects underline the social psychological dimensions of language. It is not all about words on paper, it is also about how , semiotically speaking, the body masters the physical associative signs so that the migrant identity is not betrayed. The reference to "masks" invite an unequivocal Fanonian interpretation. The speaker is self-consciously trying the "cooler mask" of English language to obtain full unconditioned professional and social access. The failure of the words and world to match encapsulates the conflictual polarities working inside bi-cultural migrants. The simile whereby her resistant face is compared to a forceful tide pins down the body's part in this affective struggle.

Writing about assimilation and access, Sara Ahmed explains why children are given greater interest: "to become a member" , she contends, " is to be willing to participate in a whole. We learn more about why willfulness is deposited in the figure of the child. The child ...signifies the not- yet- subject, as well as the subject- to come, the one who comes after" (Willful 123). In her poem, "Abbot Academy”, the poet presents a perfect image of the willful subject/child who, thanks to the mother's guidance, marches steadily towards affective power. The persona narrates how "Mami sent [her daughters] to "Abbot academy", 
to tame her girls "into ladies / who learned to act like blondes even if they / were dark-haired, olive skinned, spic-chicks like me." In images recalling Sara Ahmed's metaphor of happiness cultivation, the poet persona, in reflective tone, narrates how she "was deposited at Draper hall/ to have ... [her] edges rounded off" and her "roots/ repotted in the American soil" (The Woman 34) with the image of repotting unequivocally hammering forth the difficulty of cultural transformation. Going down the poem, we get a sharper image of how such willfulness is still entangled with fear and apprehension: "Ay Dios", the little girl prays, "help me survive this place." Notably, the persona, echoing the mother, and as clear in the head quote above, shows that such survival is only attainable through language and textuality:

And for the first time in America, He listened: the next day for English class I was assigned to Miss Ruth Stevenson Who closed the classroom door and said, "Ladies, Let's have ourselves a hell of a good time! And we did, reading Austen, Dickenson, Eliot, Woolf, until we understood We'd come to train- not tame- the wild girls Into the women who would run the world (The Woman $34)$.

The launch into the discursive world of literature and textuality transforms the bestial act of taming into training. Through the war 
machine $^{3}$ of textuality and the world of literature with its promising potentialities, the persona changes from a threatening wild beast into a human being with prospective authoritative power over the world. Art, literature, and textuality are the objects that promise happiness; they are the means whereby pride and self-confidence are promoted into the uprooted exiled migrant. The shift of tone from hushed down notes of a weighed-down apprehensive child who turns to God to rescue her into the assertive confident notes of the final lines is marked by a shift in physical activity. In contrast to the tidal movement beheld in a previous scene, the body lends itself smoothly and effortlessly to the taming, or rather, training process.

As we go through Alvarez's oeuvre, we capture vividly inscribed scenes showing the persona's developmental steps in the opted route towards affective power via language ${ }^{4}$ and textuality. In "By Accident", the poet narrates childhood scenes in which she is heard in her bedroom, singing loudly Whitman's "song of Myself" and Chaucer in Middle English, showing how

${ }^{3}$ Coined by Gilles Deleuze, the concept of "war machine" has nothing to do with war "but with a particular way of occupying, taking up, space-time, or inventing new space-times" ("Control”)

4 Alvarez expresses the same idea of language learning as an object of happiness in her autobiographical novel How the Garcia Girls Lost their Accent. In the novel , we read that "English was ...still a party favorfor me" (87 ).In her book of essays Something to Declares, she also writes extensively about the pitfalls of bilingualism and the wavering affects associated with writing in a non-native language. 
she responded to the reprimanding words of her mother saying : "These are sounds, sweet airs, / That give delight." She narrates how she stuck to her mum's advice "Keep it to yourself”!, how this advice turned her into "this paper solitude/ where...[she] both keep[s] things secret and broadcast/ ...[her] heart for all the world to read". The paper solitude parallels the earlier- described domestic solitude indirectly imposed upon the migrant parents. As is the case with native cooking, in such paper solitude, the poet creates "love portions" which is "nurture" for the soul. To offset the haunting abusive racial memories, the persona clings to the world of literature, and begins to "haunt/ the poetry shelf at the college store" (The Other Side 46). In "The Red Pickup" in which she plays on the red pickup as a symbol of unconventional girlish desires, the persona indicates how creative writing was her inner wish, the vehicle whereby she can reach 'the bigger, undivided world"(The Woman 26) , the object through which she can attain happiness:

I wanted what God wanted when He made The world, to be a driving force, a creator. And that red pickup was my only ride

Out of the common denominator (The Woman 26).

Remarkably, the persona ties her own affective potentials with textuality to the extent that "writing ... is [her] excuse / for ... unhappiness" ( The Woman 45) and that she herself wonders : "where 'd I get the idea/ that art and happiness could never jive?" 
( The Woman 14) Art and textuality are not merely her shrine, but rather her unconditioned homeland:

I learned quick: inside a year I composed a poem in English,

Directing my wary words through the wilds of strange vocabulary

To get to that intimate place I couldn't get out in person, Inside my reader's head as she read what I had written.

This was closer than friendship with none of the evasions,

Closer at times than blood with its muddled entanglements,

Outlasting passion, too, with its morning -after cautions.

I began writing in earnest - the city melted away,

The cruelty in the playground, the fierce struggles at home.

I had found the portable homeland where I wanted to belong ( The Other Side 116-117).

Despite the snowy nature of the borrowed tongue, the persona attaches herself to it as a means of survival and power. It is through writing, that the snowy cruelty of earlier abusive scenes "melted away" and the new "intimate place" in reader's psyches was attained. Her confessions that she was not able to get that place in person further foregrounds the strategic role of textuality in access. To attain positive affects via writing, she has to befriend both language and text so that the pen and the paper are as intimate as the unknown reader to whom she pours out her tormented self. The "earnest"ness with which she writes reflects the pressures imposed on her, the sense of "striving" in Spinoza's terms. She wants get rid of the shameful negative affects heaped 
on her visible/invisible body, to turn the failed exile into a fruitful experience wherein the text is "the portable homeland".

However, access into the happy world of writing is not free from its thorny affective torments; it is an experience of "hardness mixed with hurt," (the Other Side 33 ) an idea welldescribed in her poem "First Muse." In this poem, the poet registers the poet persona's mixed affects of apprehension, fears and suspicions about access into the world of creative writing:

When I heard the famous poet pronounce "one can only write poems in the tongue In which one first said Mother, I was stunned, Lately arrived in English, I slipped down Onto my seat and fought back tears, thinking Of all those notebooks filled with bogus poems I'd have to burn ...( The Woman 39).

The promised happiness is entangled with a thorny path of melancholic moments and intensive striving. Hence, a writing block would hurl the persona back to where she comes from: such "literary border guard/turning ...me back to Spanish on each line"(The Woman 39). Sometimes, as she illustrates in "Bilingual Sestina", she feels that "Some things I have to say aren't getting said / In this snowy, blond, blue-eyed, gum-chewing English" (The Other Side 3). Despite all obstacles, the persona succeeds in her Spinozian "striving". In her poem, "cleaning ladies", we behold the poet persona in her study, after "tables turned" and she 
has become published and well-received novelist ${ }^{5}$, with a " a blonde ... trim / maid" whom she "gave a signed copy of each" book. We listen to her as she relishes the nuances of the act of creation:

One of these days, I'm going to ask her in And show her that I'm also working hard, Polishing verbs, sweeping out excess words, Mopping up sticky adjectives, adverbs, Hope to make her feel as much at home In her own language as she make me feel In rooms that rhyme and sparkle with her skill (The Woman 120).

Happy as she is while writing, however, she remains conscious of the demarcating line between her native Spanish and the borrowed English -a fact pretty clear in the phrase "her own language." The liminiality of her position and the conflictual state of being inside and outside still persists. It is as if the bilingual migrant is destined to be plagued with the antithetical mix of happiness and unhappiness given his estrangement in the borrowed language no matter the level of fluency she/he has reached. No wonder, therefore, that some American non-white migrants sometimes opt to return back, to regress, physically or symbolically to their native land, culture and language.

\footnotetext{
${ }^{5}$ For a detailed engagement with creative writing as a source of affective power see her novel In the Name of Salomi in which Alvarez' mixed her own biography with the historical figure of Salomi to shed light on the nuances of female creativity and their linkage to power.
}

(The Poetics and Politics of Affect and Access...)Dr. Nagla Saad M. Hassan 


\subsection{Regreso, Native Language and Happiness}

Sara Ahmed writes that a migrant should "show signs of happiness, as signs of being or having been adjusted" (Promise 66) in order to exclude the possibility of his being dangerous to the white community. In this light, some migrants feign happiness and intentionally avoid melancholic appearance, again , to be accepted and integrated into the white community, or to use Sara Ahmed, to evade the situation of being " the object of shared disapproval, those glances that can cut you up, cut you out. An experience of alienation can shatter a world" (Feminist Killjoy).

It is in this light that we can explain what Alvarez calls "Regresso". Years after the Dominican family "had melted / into the United States of America" (The Other Side 33 ), a long life of genuine or feigned happiness, some family members opt to return back - physically, linguistically, symbolically and psychologically-to their native island and language. In her poem "Regresso" we encounter the father, who , after a long "failed exile in New York", relinquishes his keenness for access, and reverts back to his native language, wherein lies his true happiness :

Late in his life, Papi forgets himself And switches from his broken English To his muy eloquente espanol. .... Talking on the phone About his imminent regreso home After four decades living in New York, 
He starts to roll his r's and sails off Into a stream of Spanish consciousness.

After so many years of struggling To bring all of himself into ingles, and tell the great adventure of his life Now, he gives up midsentence, pours his sense Into the deeper cistern of his soul, His native tongue - la lengua más bella !(The Woman I Kept 105-106).

Although the daughter, now an adult "all-American" citizen, is uncertain about the cause of such re-use of the Spanish - whether it is old age , nostalgia or Alzheimer, she "feel[s] glad", recalling days when "in shame ...[she]'d beg/ that he speak English with ...[her] teenage friends/.... To avoid their scorn". After a long age of schizophrenic entity, or what Du Bois calls double consciousness $^{6}$, the father decides, consciously or unconsciously, to heal the schism by abandoning the fake Fanonian white mask and be himself. Ahmed explains how "shame can work as a deterrent: in order to avoid shame, a subject must enter "the contract" of... the social bond, by seeking to approximate a social ideal" (Politics of Emotion 106-107). After a long age of

\footnotetext{
${ }^{6}$ In Bois' view, this experience of duality is a fundamental aspect of African American experience. Typing his concept to racial codes, Du Bois argues that the Afro-American is torn between an American self and an African self; to abandon one of them would mean to forsake a unique aspect of his identity. For him, The conflict experienced by the Afro-American is rather intensified by virtue of the segregational racial practices which prompt the black man to conform to the way the other sees him in order to be accepted into the society. Despite this conformation, Du Bois believes, the Afro-American man does not overcome "this contradiction of double aims; hence, although he wishes "to make it possible ... to be both a Negro and an American, without being cursed," (6), he is doomed to be a victim of this sensation.
}

(The Poetics and Politics of Affect and Access...)Dr. Nagla Saad M. Hassan 
affective struggle, of feigning happiness in an exilic language to avoid shame and scorn, he throws away negative affective load, breaks "the contract" and tears "the scripts" of "normative existence" (Sara Ahmed Politics of Emotion 107) in alleged Western discourse . Notably, not only the father but also the daughter is happy with such self-reconciliation:

Now, as your final regreso draws close, Cuentanos, papi, todo en español,

All that we lost of you in English (The Woman 106).

Both of the them come to the realization that "this seeking to satisfy double two unreconciled ideas... has sent him wooing false gods and invoking false means of salvation and a times has even seemed about to make him ashamed of himself' (Du Bois 7) has engendered a false identity.

It is not only the father, therefore, who attaches joy with native language. The daughter/poet/speaker reveals in more than one place that Spanish, remains, " the first more heartfelt language,/ the accents earing down on the sweetly musical syllables, / words rooted in love/ vowels stewing in juices". She cannot overcome her mind's judgement that " the world was simple in Spanish" and that words possess "an intimacy" lacking in English;

Words so close to what I mean that I almost hear my Spanish 
Heart beating, beating inside what I say en ingles ( The Other Side 4)

Notably, in her late life, the poet persona undertakes a journey back to her home island. Describing a scene in which she and a friend are walking in the "campo", she points out how some phrases 'touches [her] more when she hears them in Spanish. How ,

saying it in Spanish goes deeper

And stirs the sediment at the bottom

Of my heart, so the feeling is stronger,

More mixed in with everything else I am,

Swirling through both the thick and thin of me,

Leaving nothing unfeeling which is why

I've been accused of overreacting

When I change countries and forget myself.

It's puzzling then that I write in English (The Woman I Kept 107).

The relationship between the intensity of affects and native language is underlined through complex compactly-constructed images. Hence, like a tide or a whirlpool, the Spanish word "swirls", "stirs" the "thin" and "thick" - with the alliterative voiceless onomatopoeic sounds paralleling the transfixing affective influence of the cherished language. The emotively stronger effect of the native words which leave "nothing unfeeling" is lexically paralleled by the words "deeper" and "bottom" "stronger. Native language is not only a source of happiness; it is equated with "self": 
As if I have to step back from myself To be able to say what I'm feelingThe way sometimes we have to get away From the place we were born or from someone We love in order to know who we are. Yes as I write in English I murmur The words over in Spanish to be sure I'm writing down the truth of what I feel

(Que escribe lo que siento de verdad.) (The Woman 108).

No matter what level of proficiency the author reaches, therefore, she continues to feel difficulty pouring herself out in their language. Just as exile itself, the experience is laden with conflicting affective fluctuations that are difficult to resolve. Accordingly, at the end of the well-crafted English-written poem above, comes the Spanish line through which the persona stamps her unwavering unending affective tension.

\section{Conclusion}

What was it that I wanted ?..

I wanted a voice... one that tell

Simply but with the mute heart's eloquence

Who I was ...

I wanted to be wanted, to belong In school, country, gender, neighborhood One of the good girls everybody loves, The heroine of the story of my life

With a happy ending 
I wanted Papa's love unhinged form shame (The Woman 149)

Clearly, therefore, to read Alvarez's poetry is to go through a trip in which the personas display their struggle to attain affective happiness and overcome passive Spinozian non-acting sorrow. The quest for happiness is entangled with the particularities of migrant experience and their attempt to gain multi-faceted access into the mainstream white community- the idea of belonging and "want"ing "to be wanted" referred to in the above quote. Significant too is that positive affects, symbolized in the above quote by the father's love, are to be "unhinged from shame". The politics of affect in Alvarez's discourse, therefore, is entangled with the multi-affective particularities of the migrant's everyday life, with the quest for "voice", for "blond blue-eyed possibilities", for being a published canonized writer despite creating in a "snowy" English within which one remains estranged and exiled. The analysis shows that the migrant's "objects of happiness" remain in a continuous state of indeterminacy and inbetweenesss paralleling the liminal position he/she occupies in the mainstream community. Like all human beings, Alvarez's ethnic heroes and "heroines" are after "a happy ending"; some realize, long late however, that they, forced by racist exclusion and blockage, have wasted their lives feigning happiness and hence embark on concrete and abstract regression 


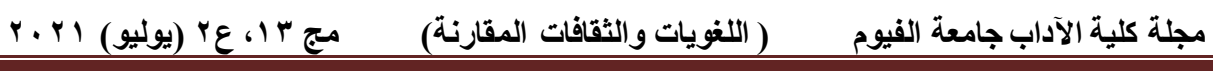

("regresso") to their native language and culture in a renewed quest for Spinozian positive affects and power. 


\section{Works Cited.}

Ahmed, Sara. Strange Encounters: Embodied Others in Postcoloniality. Routledge, 2000.

---. The Cultural Politics of Emotion. University of Edinburgh Press, 2004.

---.Killing Joy: Feminism and the History of Happiness. Signs , 35, Spring 2010, pp. 571-594.

---. The Promise of Happiness. Duke University Press, 2010.

---. On Being Included. Racism and Diversity in Institutional Life. Duke University Press, 2012.

---. Willful Subjects. Duke University Press, 2014.

---. "Feminist Killjoys (And Other Willful Subjects)". The Scholar and Feminist

Online.https://cdn.atria.nl/ezines/IAV_606605/IAV_60 6605_2010_summer/IAV_606605_2010_summer/prin t_ahmed.htm.Accessed 22 February 2020.

Alvarez, Julia . How The Garcia Girls Lost Their Accents . Workman Publishing Company, 1991.

---.The Other Side / El Otro Lado. Dutton/Penguin Group, 1995.

---.Homecoming: New and Collected Poems. Plume, 1996.

---. Something to Declare. Algonquin Books, 1998.

---. In the Name of Salome. Plume, 2001.

---.The Woman I kept to Myself. Algonquin Books of Chapel Hill, 2011.

"Affect". APA dictionary of Psychology.

https://dictionary.apa.org/affect. Accessed 10 Aug. 2019.

"Affect". Webster Merriam Dictionary. https://www.merriamwebster.com/dictionary/affect. Accessed 22 September 2020.

Berg, Ulla D. and Ana Y. Ramos-Zayas. "Racializing Affect: A Theoretical Proposition." Current Anthropology, 56, October 2015, 654-677.

Brenkman, John. Mood and Trope: The Rhetoric and Poetics of Affect. University Press, 2020.

Deleuze, Gilles. "Control and Becoming: Gilles Deleuze in Conversation with Toni Negri." Trans. Martin Joughin. 
https://thefunambulist.net/law/philosophy-control-and-becoming-aconversation-between-toni-negri-and-gilles-deleuze. Accessed 22 April $\underline{2020 .}$.

Deleuze, Gilles and Felix Guttari. Anti-Oedipus: Captialism and Schizophrenia. Trans. Robert Hurley, Mark Seem and Helen R. Lane. University of Minnesota Press, 1983.

. A Thousand Plateaus: Capitalism and Schizophrenia. University of Minnoseta Press, 1987.

Du Bois, W.E. B. The Souls of Black Folk. Modern Library, 2003.

Fanon, Frantz. Black Skins, White Masks. MacGibbon and Kee, 1968.

-----. The Wretched of the Earth. Grove Weidenfeld, 1991.

Fitzgerald, John T. Passions and Moral Progress in Greco-Roman Thought. Routledge, 2007.

Forsyth, Jessie et al. "Contemporary African Mediations of Affect and Access". Safundi, 17:2, 107-118. JSTOR, DOI:

10.1080/17533171.2016.1173963. Accessed 22 January 2021. Hampshire S. Spinoza and Spinozism. Oxford, 2005.

Harrison, Rebecca L. and Emily Hipchen. "Dialogic Waters of Julia Alvarez's "The Other Side/El Otro Lado." Inhabiting La Patria: Identity, Agency, and Antojo in the Work of Julia Alvarez. SUNY Press, 2014, pp. 159-188.

Houen, Alex, ed. Affect and Literature. University of Cambridge Press, 2020.

Jones, Rosemary. E. 'Latina Poet Chooses 'Life Of Words'. Review of The other Side." South Florida Sentinel. https://www.s un-sentinel.com/ne ws/fl-xpm-1995-08-13-9508080300story.html. Accessed 22 June 2019.

Kathleen, Steward. Ordinary Affects. Duke University Press, 2007. Knowles, Theresa. 'The Divine Dramady: Julia Alvarez's The Woman I Kept To Myself"

https://www.lighthousewriters.org/blog/divine-dramady-julia-alvarez'swoman-i-kept-myself. Accessed 24 April 2020.

Jordan, Glenn and Chris Weedon. Cultural Politics: Class, Gender, Race and the Postmodern World.. Blackwellz, 1995.

Protevi, John. "Affect and Life in Spinoza, Nietzche and Bergson" in Alex Houen's Affect and Literature. University of Cambridge Press, 2020.

(The Poetics and Politics of Affect and Access...)Dr. Nagla Saad M. Hassan 
Seigworth, Gregory F. and Melissa Gregg. Affect Theory Reader. Duke University Press, 2010.

Schaefer, Donovan. The Evolution of Affect Theory: The Humanities, the Sciences, and the Study of Power Elements in Histories of Emotions and the Senses. Cambridge University Press, 2019.

Spinoza, Baruch Spinoza Complete Works. Trans. Samuel Shirley. Hackett, 2002.

Thrift, Nigel. Non-Representational Theory : Space Politics Affect. Routledge, 2008.

Torres-Saillant, Silvio. "Homeland, Poetry, and Justice: Julia Álvarez Engages Pedro Mir" Afro-Hispanic Review, Vol. 32, No. 2 , FALL 2013,pp. 119-124

https://www.jstor.org/stable/24585149. Accessed 23 December 2020. 
الاليات الثعرية والسياسية للانفعال والوصول في مختارات من شعر جوليا ألفاريز

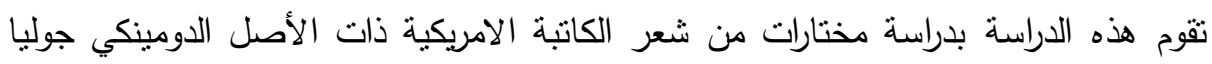

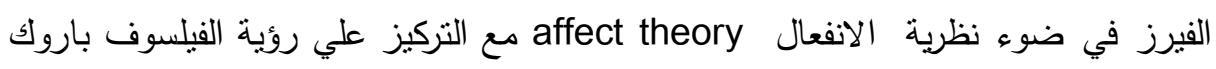

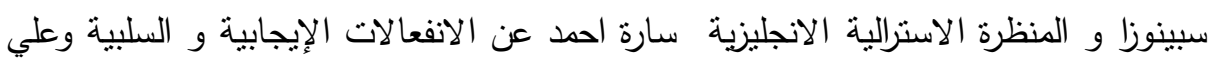

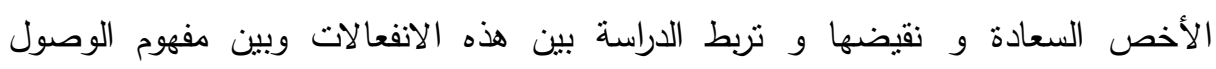

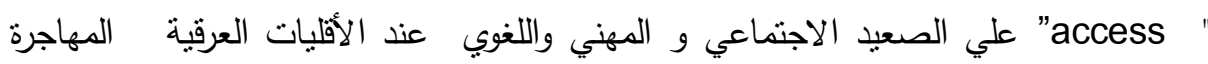

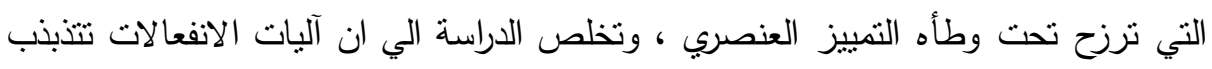

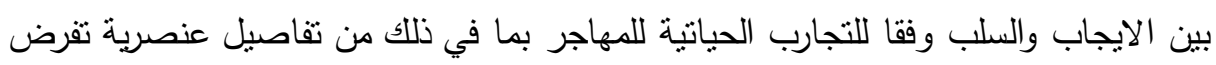

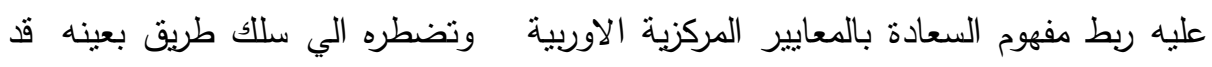

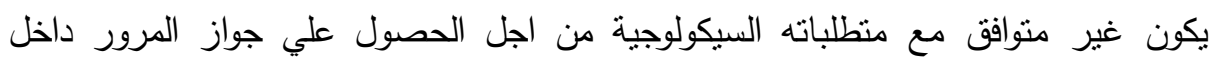

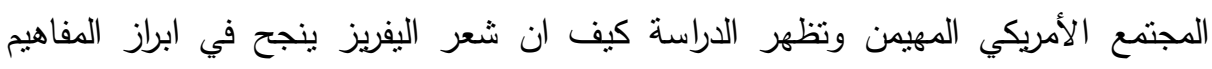

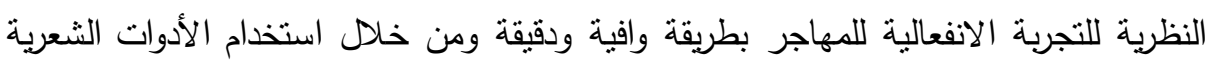

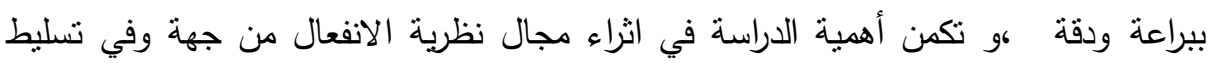

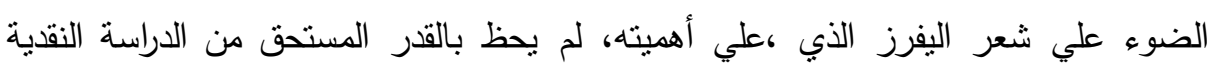

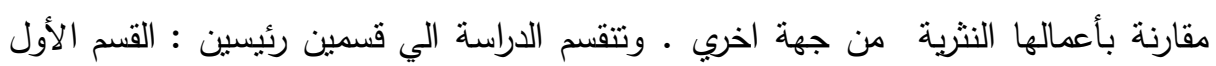

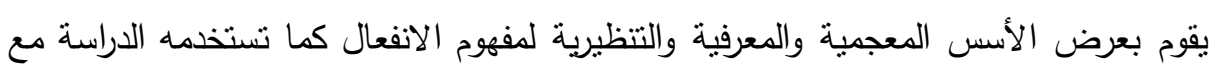
عرض لكفوم الانفعالات الإيجابية والسلبية من منظور سبينوزا وتعقيب المفكر جيل دولوز

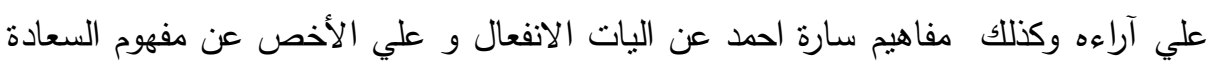

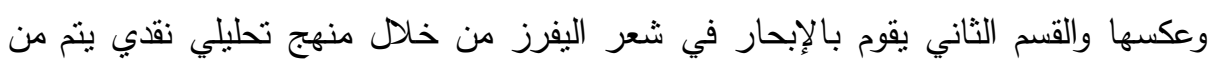

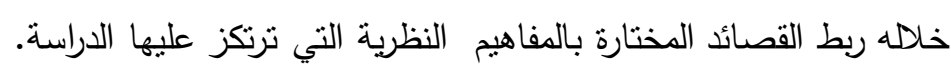

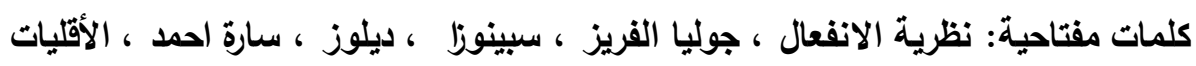
المهاجرة 